\title{
CONSIDERATION ON THE HEALTH RISK REDUCTION RELATED TO ATTAINMENT OF THE NEW PARTICULATE MATTER STANDARDS IN POLAND: A TOP-DOWN POLICY RISK ASSESSMENT APPROACH
}

\author{
JOANNA KOBZA ${ }^{1}$ JÓZEF S. PASTUSZKA ${ }^{2}$, and GABRIEL GULIS ${ }^{3}$ \\ ${ }^{1}$ Medical University of Silesia, Bytom, Poland \\ School of Public Health \\ ${ }^{2}$ Silesian University of Technology, Gliwice, Poland \\ Department of Air Protection \\ ${ }^{3}$ University of Southern Denmark, Esbjerg, Denmark \\ Unit for Health Promotion Research
}

\begin{abstract}
Policies can influence health of a population in various ways. Numerous epidemiological studies supported by toxicological investigations demonstrate a positive association between ambient concentrations of airborne particulate matter and increased adverse cardio-respiratory events, including morbidity and mortality. The aim of this paper was to present the concept of the top-down health policy risk assessment approach model developed to estimate the expected health risk reduction associated with policy aiming at attaining the new particulate matter $\leq 10 \mu \mathrm{m}$ in diameter $\left(\mathrm{PM}_{10}\right)$ standards in Poland. The top-down approach guides the analysis of causal chains from the policy to health outcomes. In this case study we tried to estimate the predicted health effects of the policy change over the past 20 years. Since Polish annual standard for $\mathrm{PM}_{10}$ changed from $50 \mu \mathrm{g} / \mathrm{m}^{3}$ in 1990 to $40 \mu \mathrm{g} / \mathrm{m}^{3}$ in 2010, we calculated the relative risk associated with decreasing $\mathrm{PM}_{10}$ in diameter to $10 \mu \mathrm{g} / \mathrm{m}^{3}$ in the annual level of $\mathrm{PM}_{10}$ for 6 adverse health effects. The relative risk slightly decreased for almost all adverse health effects, which means that the relative decrease in the incidence of health effects from the baseline incidence should range from about $0.5-0.6 \%$ for heart disease admissions to $>1 \%$ for respiratory admissions. The obtained results indicate that implementation of the new ambient air standards could influence improvement of the health status of Polish population. A top-down policy health risk assessment model can be one of the main tools in this process, providing harmonized guidance how to seek evidence-based information, which could serve policy-makers.
\end{abstract}

Key words:

Particulate matter, Top-down approach, Policy, Health outcome, Health risk assessment, Environmental exposure

\footnotetext{
This work was supported by the European Commission, 2nd Community Action Plan on Public Health Program via Directorate for Health and Consumers (DG-SANCO) and Executive Agency for Health and Consumers (EAHC), through the grant agreement No. 20081105, "Risk Assessment from Policy to Impact Dimension" (RAPID). Project manager: Prof. G. Gulis.

Received: August 20, 2014. Accepted: April 13, 2015.

Corresponding author: J. Kobza, Medical University of Silesia, School of Public Health, Piekarska 18, 41-902 Bytom, Poland (e-mail: koga1@poczta.onet.pl).
} 


\section{INTRODUCTION}

Policies on air quality and its impact on health constitute major environmental health issues. According to the World Health Organization (WHO), environment is estimated to account for almost $20 \%$ of all deaths in the WHO European Region [1]. There are many air pollutants that are important from the health point of view, such as: suspended particulate matters, sulphur dioxide, nitrogen dioxides, ammonia, carbon monoxide, ozone, polycyclic aromatic hydrocarbons and others.

Generally, adverse health effects related to exposure to air pollutants are connected with the dose, although the dose-effect relationship is often complicated in character. On the other hand, the amount/dose of the absorbed pollutants depends mainly on their concentrations and duration of exposure. Therefore, it should be concluded that for an individual population exposed to a specific air pollutant its concentration in the air is one of the key factors being responsible for the occurring adverse health effects.

For this reason establishing some scientifically documented limits/standards of concentration levels, which could be accepted from the health point of view, seems to be a very rational action in the environmental health monitoring. Among air pollutants, airborne particles play a special role, in terms of health impact, since they can be carriers of other toxic, carcinogenic or allergic substances.

Various investigations identify key health outcomes to be consistently associated with airborne particulate matter. Numerous epidemiological studies, supported by toxicological investigations, demonstrate a positive association between ambient concentrations of airborne particulate matter and increased adverse respiratory and cardiovascular events [2-4], including morbidity and mortality [5-14]. Also exposure during the last month of pregnancy can contribute to the risk of lower birth weight and the risk of preterm birth in infants [15-19].
Premature deaths from all causes, including cardiopulmonary deaths and lung-cancer deaths, could be prevented annually if long-term exposure to particulate matter $(\mathrm{PM}) \leq 10 \mu \mathrm{m}$ in diameter levels was reduced, even by very small and achievable amounts $[20,21]$. The Apheis (Air Pollution and Health: a European Information System) study [21] assumes that, due to the reduction in total mortality, the potential gain in life expectancy of a 30-yearold person would range from 1 month to more than 2 years if the annual mean of converted $\mathrm{PM}_{2.5}$ would not exceed $15 \mu \mathrm{g} / \mathrm{m}^{3}$. It is important to note, though, that such a benefit may be achieved only much later than expected. Therefore, consistent implementation of a range of policies could lead to significant reductions in population exposure and associated health impacts. Despite insufficient knowledge on the exposure-effect relationships between particles with an aerodynamic diameter $(\mathrm{d}) \leq 10 \mu \mathrm{m}\left(\mathrm{PM}_{10}\right)$ and human health, $\mathrm{PM}_{10}$ standards have been developed. In 1987 in the WHO guidelines [22], the recommended level, below which health effects were unlikely to occur (around $100 \mu \mathrm{g} \times \mathrm{m}^{-3}$ annual mean for both smoke and sulphur dioxide), was set and a safety factor of 2 was applied.

It should be stated, however, that the World Health Organization concluded that health risks are present at any level of particles. This conclusion has been absolutely fundamental and has strongly influenced the philosophy of the policy of airborne particles in the context of their impact on human health. Beginning with the 2nd revision of the WHO guidelines for particulate matter in 2000 [23], and continuing with the most recent ones [24], the concept of no observed effect level was abandoned in favor of a model in which no threshold of adverse effects within the usual ambient range was assumed [25]. Under this concept, the recommended value of particulates concentration, while set at a level that gave reasonable protection for public health, was higher than that at which the effect could be observed. 
This shift in thinking was strongly influenced by accumulating results of time-series studies of mortality, which tended not to observe a threshold of effect within the ambient range [25]. The Agency for Public Health Education Accreditation (APHEA) study of 29 European cities [26] can be one of the examples. Authors of this paper have documented that no threshold appeared in the relationship between exposure to $\mathrm{PM}_{10}$ and daily mortality. No threshold relationship also applied to the long term effects.

Polish experiences provide examples that reveal health benefits following legislation progressively limiting PM levels. The implemented policy has led to appreciable lowering of pollutant levels. Achievement of this target required implementation of a range of policy settings and enforcing emissions standards at the beginning of the 1990s.

The objective of this paper is to present the concept of the top-down policy risk assessment approach, developed to estimate the predicted health risk reduction associated with policy aiming at attaining new particulate matter standards in Poland. Our consideration refers only to the ambient air.

The study was a part of the European Commission's public health research - RAPID (Risk Assessment from Policy to Impact Dimension) project [27]. The aim of the project was to develop and provide policy makers with methodological guide for the assessment of a complex impact structure of policies in relation to the health of a population [28].

\section{MATERIAL AND METHODS}

We performed a study based on a literature review and documentation analysis. Epidemiological literature from the period 1989-2012 and electronic databases PubMed/ MEDLINE, Embase and CINAHL were searched using the following keywords: "air pollutants," "airborne particles," "PM ${ }_{10}$," "health hazards," "health impact assessment." As documentation, all Polish laws related to

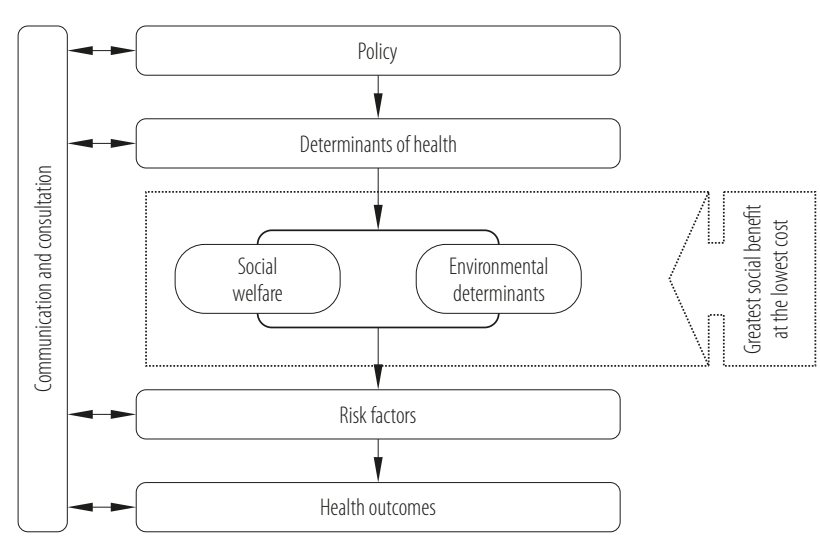

Fig. 1. A top-down policy health risk assessment model approach

air pollution and health statistics were studied for the period 1980-2010.

The top-down risk assessment approach follows a logical structure, which starts with the selection of a concrete policy, followed by a description of wider determinants of health influenced by the policy and the risk factors linked to these determinants of health. As a final step, health outcomes related to the selected risk factors are identified. Using this model should allow quantification of health outcomes from an existing or a new policy through its implications on health determinants and associated risk factors, and provide decision-makers with practical information on the expected changes of health outcomes. This approach guides the analysis of causal chains from the policy to health outcomes. A general scheme of such a model is presented in Figure 1. Methodological considerations were pilot tested. The authors tried to estimate the predicted/expected health effects of the policy change. It is important to notice that the main aim of this paper was to develop the assessment model, not the assessment itself. Development of the "full chain" approach model is the key issue here and naturally, the model does not change due to changes in data. It is a robust model and can be applied both with older and more recent data. The important thing; however, is to draw the impact chain across 4 levels. 


\section{RESULTS}

\section{Policy description}

General remarks

Air pollution can basically be regulated in various ways [29]: by emission standards, by air quality standards and by emission taxes. The classical, and in principle the soundest way, is to limit emissions from a source (1 producer), entire country (emission quotas), or even from a sector (for example, emission level from heating plants or from power stations may be restricted). The pragmatic way is to state how much pollution there may be in particular ambient air and regulate the dispersion accordingly. The 1st approach, i.e., establishing emission standards, has been attempted for centuries. The 2nd approach is fairly new, being dependent upon more or less sophisticated measurements and computational techniques. In modern practice, these 2 approaches work together with rules and regulations for both emissions and concentrations.

\section{Analysis of regulation of air pollution}

from historical perspective in Poland

Polish national standards have been developed according to the development of knowledge on health implications of inhalation of air pollutants, although with some delay comparing to the so-called Western-European countries and the USA. Therefore, first, a standard for the dust deposition together with a standard for concentration of the total suspended particles have been established. A short review of historical changes of Polish standards for airborne particles is contained in Table 1 .

\section{Period 1980-1990}

The particulate pollution of ambient air has been assessed by measuring concentration of the total suspended particles matter (TSP) and the deposition level [29,31]. The standard for the deposition was $250 \mathrm{t} /\left(\mathrm{km}^{2} /\right.$ year $)$ and, next, $50 \mathrm{t} /\left(\mathrm{km}^{2} / \mathrm{year}\right)$. In Upper Silesia, the daily values of the TSP levels were often $500-1000 \mu \mathrm{g} \times \mathrm{m}^{-3}$, while the deposition of particles was about $600 \mathrm{t} /\left(\mathrm{km}^{2} / \mathrm{year}\right)$. However, in some areas, for example in Zabrze, even values such as $800 \mathrm{t} /\left(\mathrm{km}^{2} /\right.$ year $)$ were reported, i.e., the appropriate standards were significantly exceeded.

Up until the political and economic changes in Poland in the 1980s, all environmental data was confidential. Access to these historical materials (reports and papers) is now unlimited, but the analysis of the published and unpublished data should be made carefully (even national journal papers were typically not reviewed by independent reviewers). Historical $\mathrm{PM}_{10}$ data in Poland cannot be immediately used because the Polish Standard for $\mathrm{PM}_{10}$ established in 1984 indicated that the measurements of $\mathrm{PM}_{10}$ level could be carried out by various samplers without any selector of coarse particles. As a result, for some years monitoring stations in Poland reported the levels of $\mathrm{PM}_{10}$ obtained by various methods and by using various samplers, including samplers used earlier for collecting total suspended particles.

These problems were investigated [37,38], and the reports have shown that in Poland it is possible to use the existing/reported PM concentration data to predict historical values of $\mathrm{PM}_{10}$, but only for the selected areas and for selected periods during the past 30 years. In addition, it should be noted that the $\mathrm{PM}_{10} / \mathrm{TSP}$ ratio has changed significantly along with time. Significant political and economic transformation in Poland changed the sources of anthropogenic pollution. Emissions of air pollutants from the metallurgical, chemical, and coal mining industries were reduced in few regions, especially in Upper Silesia. Very soon it became clear that it was mostly a reduction of emissions of particles that were larger than $10 \mu \mathrm{m}$ - from a technical point of view, it is relatively easy to remove coarse particles (especially $>10 \mu \mathrm{m}$ ) from the emitted load of pollutants. On the other hand, decreasing emissions of fine particles needs more advanced and costly techniques, typically using electrostatic collection of particles. 
Table 1. Development of Polish regulations concerning ambient air

\begin{tabular}{|c|c|c|c|}
\hline Year & Established factor & Standard value & Referred standard \\
\hline 1966 & deposition of dust & $\begin{array}{l}250 \mathrm{~g} /\left(\mathrm{m}^{2} / \text { year }\right) \text { and } 40 \mathrm{~g} /\left(\mathrm{m}^{2} / \text { year }\right) \text { for } \\
\text { protected areas }\end{array}$ & $\begin{array}{l}\text { the Act of } 13 \text { September on concentration limits } \\
\text { of substances in ambient air [30] }\end{array}$ \\
\hline 1966 & $\mathrm{PM}_{20}$ but really TSP* & $\begin{array}{l}\mathrm{D}_{30}=600 \mu \mathrm{g} / \mathrm{m}^{3} \\
\mathrm{D}_{30}=200 \mu \mathrm{g} / \mathrm{m}^{3} \text { for protected areas }\end{array}$ & $\begin{array}{l}\text { the Act of } 13 \text { September on concentration limits } \\
\text { of substances in ambient air [30] }\end{array}$ \\
\hline 1980 & TSP & $\begin{array}{l}D_{a}=22 \mu \mathrm{g} / \mathrm{m}^{3} \text { for protected areas } \\
D_{a}=11 \mu \mathrm{g} / \mathrm{m}^{3} \text { for the special protected } \\
\text { areas } \\
D_{30}=500 \mu \mathrm{g} / \mathrm{m}^{3} \text { for protected areas } \\
D_{30}=150 \mu \mathrm{g} / \mathrm{m}^{3} \text { for the special } \\
\text { protected areas }\end{array}$ & $\begin{array}{l}\text { the Act of } 31 \text { November } 1980 \text { on ambient air } \\
\text { protection against pollution [31] }\end{array}$ \\
\hline 1990 & $\begin{array}{l}\text { suspended dust, later } \\
\text { defined as } \mathrm{PM}_{10} \text {, but in } \\
\text { reality TSP** }\end{array}$ & $\begin{array}{l}\mathrm{D}_{\mathrm{a}}=50 \mu \mathrm{g} / \mathrm{m}^{3} \\
\mathrm{D}_{\mathrm{a}}=40 \mu \mathrm{g} / \mathrm{m}^{3} \text { for the special } \\
\text { protected areas } \\
\mathrm{D}_{30}=280 \mu \mathrm{g} / \mathrm{m}^{3} \\
\mathrm{D}_{30}=200 \mu \mathrm{g} / \mathrm{m}^{3} \text { for the special } \\
\text { protected areas }\end{array}$ & $\begin{array}{l}\text { the Act of } 12 \text { February } 1990 \text { on air protection } \\
\text { against pollution [32] }\end{array}$ \\
\hline 1998 & TSP & $\begin{array}{l}D_{a}=50 \mu \mathrm{g} / \mathrm{m}^{3} \\
D_{a}=40 \mu \mathrm{g} / \mathrm{m}^{3} \text { for health-resort areas } \\
D_{30}=280 \mu \mathrm{g} / \mathrm{m}^{3} \\
D_{30}=250 \mu \mathrm{g} / \mathrm{m}^{3} \text { for health-resort } \\
\text { areas }\end{array}$ & $\begin{array}{l}\text { the Act of } 28 \text { April } 1998 \text { on permissible } \\
\text { concentrations of pollutants in the air [33] }\end{array}$ \\
\hline 1998 & $\mathrm{PM}_{10}$ & $\begin{array}{l}D_{a}=50 \mu \mathrm{g} / \mathrm{m}^{3} \\
D_{a}=40 \mu \mathrm{g} / \mathrm{m}^{3} \text { for health-resort areas } \\
D_{30}=280 \mu \mathrm{g} / \mathrm{m}^{3} \\
D_{30}=250 \mu \mathrm{g} / \mathrm{m}^{3} \text { for health-resort } \\
\text { areas }\end{array}$ & $\begin{array}{l}\text { the Act of } 28 \text { April } 1998 \text { on permissible } \\
\text { concentrations of pollutants in the air [33] }\end{array}$ \\
\hline 2002,2003 & $\mathrm{PM}_{10}$ & $\begin{array}{l}D_{a}=40 \mu \mathrm{g} / \mathrm{m}^{3} \\
D_{1}=280 \mu \mathrm{g} / \mathrm{m}^{3}\end{array}$ & $\begin{array}{l}\text { the Act of } 22 \text { June } 2002 \text { on admissible levels of } \\
\text { certain substances, in air, alarm levels of certain } \\
\text { substances in air and margin of tolerance for } \\
\text { the maximum levels of certain substances [34] } \\
\text { the Act of } 5 \text { December } 2003 \text { on values of } \\
\text { references for certain substances in air [35] }\end{array}$ \\
\hline 2012 & $\mathrm{PM}_{2.5}$ & $\mathrm{D}_{\mathrm{a}}=40 \mu \mathrm{g} / \mathrm{m}^{3}$ & $\begin{array}{l}\text { the Act of } 24 \text { August } 2012 \text { on levels of certain } \\
\text { substances in air [36] }\end{array}$ \\
\hline
\end{tabular}

PM - particulate matter; TSP - total suspended particles.

$\mathrm{D}_{30}$ - maximal accepted concentration level during $30 \mathrm{~min}, \mathrm{D}_{\mathrm{a}}$ - maximal accepted concentration level during a year (annual standard); $\mathrm{D}_{1}-$ maximal accepted concentration level during $1 \mathrm{~h}$.

* Although this standard was established for airborne particles smaller than $20 \mu \mathrm{m}$, the suggested samplers enabled to collect TSP only.

** Suggested samplers enabled to collect only TSP.

Period 1990-2002

Polish legislation has concentrated on implementing the European Union's standards. This process was not easy because since 1990 the fractionation of the total suspended particles (TSP) was attempted in Europe by measuring airborne particles with an aerodynamic 
diameter $\leq 10 \mu \mathrm{m}\left(\mathrm{PM}_{10}\right)$. A major part of $\mathrm{PM}_{10}$ is often of a natural origin (sea spray and mineral dust), and therefore, it is also important to measure fine particles, i.e., smaller than $2.5 \mu \mathrm{m}\left(\mathrm{PM}_{2.5}\right)$ or even submicrometer particles, $\mathrm{PM}_{1}$ [29].

During this period in Poland, the Ministry for Environmental Protection, Natural Resources and Forests was created and the standards for $\mathrm{PM}_{10}$ were established (annual level $50 \mu \mathrm{g} \times \mathrm{m}^{-3}$ ) [32]. As we highlighted above, a significant political and economic transformation in Poland changed the sources of anthropogenic pollution. For example, total emissions of dust from Polish territory decreased from $1950 \mathrm{Gg}$ in 1990 to $470 \mathrm{Gg}$ in 2002 [34,35]. Very soon it became clear that it was mostly a reduction of emissions of particles larger than $10 \mu \mathrm{m}$. Nevertheless, rapid decreases in concentration of TSP and the deposition levels were observed (in Upper Silesia daily levels of TSP were less than $100 \mu \mathrm{g} \times \mathrm{m}^{-3}$, while the deposition level decreased below $50 \mathrm{t} / \mathrm{km}^{2} /$ year).

\section{Recent period:2002-2012}

Polish regulations that were in force up to 1984, applied to the total suspended particles (TSP), which resulted in extremely high limits when compared to the annual and daily limiting values established by the Directive for $\mathrm{PM}_{10}$ [39]. In 2002 the Polish Ministry of Environment established new, standards for $\mathrm{PM}_{10}: 24-\mathrm{h}$ standard $50 \mu \mathrm{g} \times \mathrm{m}^{-3}$ with acceptable tolerance of $10 \mu \mathrm{g} \times \mathrm{m}^{-3}$, in 2003 and $5 \mu \mathrm{g} \times \mathrm{m}^{-3}$, in 2004, and the annual standard of $40 \mu \mathrm{g} \times \mathrm{m}^{-3}$ with acceptable tolerance of $3.2 \mu \mathrm{g} \times \mathrm{m}^{-3}$ in 2003 , as well as $1.6 \mu \mathrm{g} \times \mathrm{m}^{-3}$ in 2004 [34,35]. New standards established in 2008-2010 [40-42] introduced the annual standard for $\mathrm{PM}_{10}$ as $40 \mu \mathrm{g} \times \mathrm{m}^{-3}$ without any tolerance.

This work has certainly contributed to a significant improvement of air quality in Poland, especially after 1990. It should be also noted that significant economic transformations in Poland during the last 20 years have changed the profile of anthropogenic pollution sources, and the traffic emissions of particles have become a new important source of airborne particles. On the other hand, municipal emissions, along with industry, still contribute the most to the aerosol particles on Polish territory. Therefore, the possibility of establishing new emission limits for the municipal sources as well as for cars and trucks should be considered.

\section{European policy context}

Particulate matter exposure reduction targets for the sake of protection of human health are included in several European Union (EU) documents. In 1999 the European Commission (EC) included $\mathrm{PM}_{10}$ monitoring and limits values in the Air Quality Directive [39] and new limit values for several atmospheric pollutants were introduced in 2005, and met by 2010 (a mean $\mathrm{PM}_{10}$ of $40 \mu \mathrm{g} / \mathrm{m}^{3}$ for 2005 , and $20 \mu \mathrm{g} / \mathrm{m}^{3}$ in 2010 were the targets to achieve). The mass concentration level of $\mathrm{PM}_{10}$ has been established as the main parameter used for measuring and controlling particulate pollution of ambient air.

One of the key documents in European environmental policy, approved recently, is the EC Directive on ambient air quality and cleaner air for Europe [43], which regulates ambient air concentrations of pollutants including $\mathrm{PM}_{10}$ and $\mathrm{PM}_{2.5}$ indicating upper and lower assessment thresholds for $\mathrm{PM}_{10}$ to be achieved in the nearest future by the EU Member States. It has been transposed into national legislation of all the EU countries. The European Environment Agency in its reports on air quality in Europe [44,45] highlighted that although in Poland the annual $\mathrm{PM}_{10}$ standard $\left(40 \mu \mathrm{g} \mathrm{m}^{-3}\right)$ is still exceeded in many locations, a considerable improvement in the number of exceedances of $\mathrm{PM}_{10}$ has been reported over the last years (Table 2).

\section{Determinants of health}

Particulate matter regulations implemented in Poland over the past 20 years have introduced quality standards for ambient air and have reduced the most serious air 
Table 2. Development of the European Union legislation related to the limit values of $\mathrm{PM}_{10}$ in ambient air

\begin{tabular}{|c|c|}
\hline Year & European Commission regulations \\
\hline 1996 & $\begin{array}{l}\text { Council Directive, Air Quality Framework Directive (96/62/EC) described the basic principles as to how air quality } \\
\text { should be assessed and managed in the Member States; it listed the pollutants for which air quality standards and } \\
\text { objectives would be developed and specified in legislation [46] }\end{array}$ \\
\hline 1997 & $\begin{array}{l}\text { Council Decision (97/101/EC) establishing a reciprocal exchange of information and data from networks and } \\
\text { individual stations measuring ambient air pollution within the Member States [47] }\end{array}$ \\
\hline 1999 & $\begin{array}{l}\text { Air Quality Directive }(1999 / 30 / \mathrm{EC}) \text { related to the limit values for } \mathrm{PM}_{10} \text { in ambient air, 24-h limit: } 50 \mu \mathrm{g} / \mathrm{m}^{3} \text { and fixed } \\
\text { the annual limit value of } 40 \mu \mathrm{g} / \mathrm{m}^{3} \text { to be achieved 1st Jan } 2005 \text { and } 20 \mu \mathrm{g} / \mathrm{m}^{3} \text { in } 2010 \text { [39] }\end{array}$ \\
\hline 2000, 2002 & $\begin{array}{l}\text { Directives of the European Parliament and of the Council (2000/69/EC and 2002/3/EC) specified the format and } \\
\text { content of the Member States's Annual Report on ambient air quality in their territories }[48,49]\end{array}$ \\
\hline 2004 & $\begin{array}{l}\text { Commission Decision (2004/461/EC) laying down a questionnaire for annual reporting on ambient air quality } \\
\text { assessment [50] }\end{array}$ \\
\hline 2008 & $\begin{array}{l}\text { Directive on ambient air quality and cleaner air for Europe }(2008 / 50 / \mathrm{EC}) \text { for } \mathrm{PM}_{10} \text {, the exemption from the limit } \\
\text { value for a } 3 \text { year period, ending in June } 2011 \text { [43] }\end{array}$ \\
\hline
\end{tabular}

$\mathrm{PM}_{10}$ - particulate matter $\leq 10 \mu \mathrm{m}$ in diameter.

pollutants, and thus, contributed to limiting significant negative impact and risks to the health of the population. In general, the regulations belong to complex actions with an objective to improve health condition of the population. By reducing the standard, i.e., the maximum concentration level of a pollutant, any air pollution regulation has influence on the environmental determinants of health. Yet, health status of a population is influenced by many other factors, not only air pollution.

However, regulations on air pollution affect health in a direct way also through other determinants of health. A regulation on air pollution standards affects industry and technology, which need to change operational processes, and to introduce new technologies to minimize emissions. This leads to changes in employment and social determinants of health. Another form of an influence is through better air quality; if a regulation achieves its objective and air becomes clearer this might lead to more people doing physical activity, and to a change in behavioral determinants of health.

A full model of calculating the impact of a change in regulation on health outcomes would require inclusion of these pathways as well. However, due to the simplicity reason in our assessment, we decided to model only the direct, environmental determinants of health driven pathway as the most likely to be the most powerful pathway.

\section{Risk factors}

Air quality includes many different potential hazards, which under certain conditions become risk factors in relation to the exposed population. Concentrations of sulphur dioxide $\left(\mathrm{SO}_{2}\right)$, nitrogen dioxide $\left(\mathrm{NO}_{2}\right)$, carbon monoxide (CO), other chemicals in the air, as well as their mixtures, are all potential risk factors in relation to a given population. In this work, we focus on particulate matter.

The relative risk is defined by standard epidemiological literature [i.e., 51,52]. Most studies estimating relations between PM and adverse health effects assume an exponential concentration - response function [53]. The most frequently used measure to express the impact of a risk factor on health is the relative risk (RR) or odds ratio (OR). The relative risk $\mathrm{RR}_{\Delta x}$ associated with the change in ambient particulate matter (PM) levels $\Delta x$, seems to be the best parameter for this analysis. 
The relative risk $\left(\mathrm{RR}_{\Delta \mathrm{x}}\right)$ is defined as follows:

$$
\mathrm{RR}_{\Delta \mathrm{x}}=\frac{\mathrm{y}}{\mathrm{y}_{0}}=1+\frac{\Delta \mathrm{y}}{\mathrm{y}_{0}}
$$

where:

$y$-the incidence of a health endpoint of interest at the PM level $x$, $\Delta y$ - describes the change in the incidence of health effects from the baseline incidence, $\mathrm{y}_{0}$ (the incidence at PM concentration $\mathrm{x}_{0}$, attending the appropriate standard) to y (the incidence for PM concentration equal to $\mathrm{x}$ ).

Typically, the relative risk is calculated for the growing concentration of airborne particles, which means $\Delta \mathrm{x}=\mathrm{x}-$ $x_{0}>0$, therefore $\Delta y>0$, and $R_{\Delta x}=y / y_{0}>1$. Assuming that the concentration level will decrease $(\Delta x<0)$, the relative risk should be $<1$. Such a defined relative risk could be a suitable factor for characterization of the various scenarios of expected health effects related to the implementation of PM standards.

Most epidemiological studies estimating relations between PM and adverse health effects assume an exponential concentration - response function. In this model [51]:

$$
\mathrm{y}=\mathrm{Be} \mathrm{e}^{\beta \mathrm{x}}
$$

where:

$\beta$ - the coefficient of ambient PM concentration,

$\mathrm{B}$ - the incidence at $\mathrm{x}=0$, that is, when there is no ambient PM.

From equation (2) the difference $\Delta y=y-y_{0}$ can be calculated:

$$
\Delta y=B\left(e^{\beta x}-e^{\beta x_{0}}\right)=B\left(e^{\beta\left(x_{0}+\Delta x\right)}-e^{\beta x_{0}}\right)=B e^{\beta x_{0}}\left(e^{\beta(\Delta x)}-1\right)
$$

Using equation (2) the above equation can be written:

$$
\Delta y=y_{0}\left(e^{\beta(\Delta x)}-1\right) \text { or } \frac{\Delta y}{y_{0}}+1=e^{\beta(\Delta x)}
$$

Combining equations (1) and (4) the following can be obtained:

$$
\operatorname{RR}_{\Delta x}=e^{\beta(\Delta x)}
$$

Generally, estimates of $\beta$ can be taken from epidemiological literature. We calculated appropriate values of $\beta$ (Table 3 ) from the weighted averages of the relative risk of respiratory admissions for a $100 \mu \mathrm{g} / \mathrm{m}^{3}$ increase in $\mathrm{PM}_{10}$ in the ambient air, published by Schwartz [51]. Data for daily mortality was taken from Schwartz [51] and from O’Neill [52].

Since Polish annual standard for $\mathrm{PM}_{10}$ changed from $50 \mu \mathrm{g} / \mathrm{m}^{3}$ in 1990 to $40 \mu \mathrm{g} / \mathrm{m}^{3}$ in 2010, we calculated the relative risk associated with $10 \mu \mathrm{g} / \mathrm{m}^{3}$ decrease in the annual level of $\mathrm{PM}_{10}$ (Table 3). The relative risk associated with a $10 \mu \mathrm{g} / \mathrm{m}^{3} \mathrm{de}$ crease in the annual level of $\mathrm{PM}_{10}$ was calculated for 6 adverse health effects: all respiratory admissions, chronic obstructive pulmonary disease (COPD), pneumonia admissions, heart failure, dyshrythmia, asthma emergency room visits and daily mortality. The relative risk ranged from 0.971 (asthma emergency room visit) to 0.995 (dysrhytmia) and almost 1 (daily mortality). The obtained results indicate that implementation of the new Polish standard could result in an improvement of the health status of Polish population.

\section{Health outcome}

Assuming that the concentration level of $\mathrm{PM}_{10}$ decreases according to the change in the Polish standard, the relative risk slightly decreases for almost all the adverse health effects. This means that the relative decrease in the incidence of health effects from the baseline incidence $\left(\Delta y / y_{0}\right)$ should range from about $0.5-0.6 \%$ for heart disease admissions to more than $1 \%$ for respiratory admissions. In particular, the decrease in asthma emergency room visits reaching almost $3 \%$ seems to be significant, but the real situation may not be so optimistic due to the growing role of other asthma-generating factors. Nevertheless, the relative decrease in all the health effects, excluding asthma 
Table 3. Relative risk associated with $10 \mu \mathrm{g} / \mathrm{m}^{3}$ decrease in the annual level of $\mathrm{PM}_{10}$ in the ambient air

\begin{tabular}{lccc}
\hline \multicolumn{1}{c}{ Adverse health effect } & $\begin{array}{c}\beta \\
{\left[\mathrm{m}^{3} / \mu \mathrm{g}\right]}\end{array}$ & $\mathrm{RR}_{\Delta \mathrm{x}}$ & $\begin{array}{c}\Delta \mathrm{y} / \mathrm{y}_{\mathrm{o}} \\
{[\%]}\end{array}$ \\
\hline All respiratory admissions & $1.22 \times 10^{-3}$ & 0.988 & -1.2 \\
COPD & $1.74 \times 10^{-3}$ & 0.983 & -1.7 \\
Pneumonia admissions & $1.22 \times 10^{-3}$ & 0.988 & -1.2 \\
Heart failure & $0.58 \times 10^{-3}$ & 0.994 & -0.6 \\
Dysrhytmia & $0.49 \times 10^{-3}$ & 0.995 & -0.5 \\
Asthma emergency room visits & $2.93 \times 10^{-3}$ & 0.971 & -2.9 \\
Daily mortality & $0.05 \times 10^{-3}-0.86 \times 10^{-3}$ & $1.000-0.991$ & $\leq-0.9$ \\
\hline
\end{tabular}

COPD - chronic obstructive pulmonary disease; $\mathrm{PM}_{10}$ - particulate matter $\leq 10 \mu \mathrm{m}$ in diameter; $\mathrm{RR}_{\Delta \mathrm{x}}-$ relative risk; $\Delta \mathrm{y} / \mathrm{y}_{\mathrm{o}}-$ the relative decrease in the incidence of health effects from the baseline incidence.

$\beta$ calculated from Schwartz [51] and O'Neill et al. [52].

and daily mortality, is $5.2 \%$ (summarizing $\Delta y / y_{0}$ for all health effects except of the last 2).

During future studies the updated monitoring data must be carefully considered, as it may have impact on the decision-making and/or subsequent steps in the change in the national particulate standards (also for $\mathrm{PM}_{2.5}$ ). In particular, their grouping or dividing into several subcategories, such as long-term exposure to $\mathrm{PM}_{10}$, additional exposure to environmental tobacco smoke (ETS), and atmospheric sulphur dioxide may reduce or increase their significance, especially, when other non-environmentally related risk factors, such as: smoking, alcoholism or immune-suppression, are considered [54].

\section{DISCUSSION}

Polish population health statistics in the period 19902010 reflect a positive trend - a steady decrease in mortality rates, due to cardiovascular disease (CVD) and due to respiratory diseases, has been observed over the past 20 years. This decrease has many reasons, and it is hard to assess how much of the recent fall could be explained by reductions in major risk factors (life style, environmental, health system).

As it was mentioned above, in terms of chronic diseases of the lower respiratory tract it is important to note that there are slight differences between various regions in Poland. The highest CVD incidence is in the most urban agglomerations; Upper Silesian region and Łódź, where PM standards have been still considerably exceeded [55]. For example, in Zabrze, Upper Silesia, during 2 days on January 2006 concentration of $\mathrm{PM}_{10}$ reached the level of $513 \mu \mathrm{g} \times \mathrm{m}^{-3}$ [56]. It is important to note that, as a rule, in Poland, residential sources (household coal combustion) are mainly responsible for this situation [57,58]. We indicate here the contribution of residential emission sources only.

In the population of Polish males in the 2nd half of the 20th century, the risk of lung cancer grew most rapidly, and this cancer dominated the picture of cancers among men. Over the last 2 decades this increase has been stopped and reversed. The incidence of lung cancer and mortality has grown especially dramatically in the female population in the last 2 decades, and in the case of women, lung cancer has become cancer number 2 [59].

The respiratory system diseases mortality rate was decreasing steadily, but a long decrease ended in 1994, and now we observe the same level as at the beginning of the 1990s. It is important to notice that the respiratory system mortality rate is higher in the countryside than in the cities [55]. As regards asthma and allergies, recent studies 
show a significant increase in Poland in the incidence of both, and the values are similar to those observed in highly developed countries, where it is estimated at 20-30\%. The highest values of allergies (allergic rhinitis) and asthma prevalence rates are reported in children urban inhabitants, $25 \%$ more than in the rural areas. Although finding trends in the prevalence of allergic disorder and respiratory symptoms is rather difficult; a study carried out in children aged 7-10 has indicated some positive results in health status of these children due to the improvement of ambient air quality [60].

Potential contribution of environmental risk factors in cardio-respiratory diseases mortality remains unclear. The prevalence of smoking in men and women has also dropped considerably over the past 20 years. Changes in other lifestyle risk factors (i.e., dietary changes, alcohol consumption, physical activity) might also have played an important role. Some experts highlight lifestyle risk factors reduction [61] as the main contribution to the CVD fall, others the evidence based treatment (pharmacotherapy, i.e., statins, coronary angioplasty and angiography) and better rescue system [62].

The most recent research based on modeling study using the Improving Mood - Promoting Access to Collaborative Treatment (IMPACT) model explains $37 \%$ of the decrease in the death rate from coronary heart disease over the past 20 years in Poland, as attributable to evidence based medical treatments, and about $54 \%$ of the fall as related to the changes in the lifestyle risk factors [61]. The same research confirms that among the major risk factors $15 \%$ of the observed decrease in mortality was related to the reduced smoking in men (negligible in women). Better health outcomes of the population have been achieved mainly due to the implementation of health promotion programs, effective legislation, more active public health policy in CVD prevention and treatment in Poland since the beginning of 1990s.

The developed model for assessment of a regulation's population health impact provides a great opportunity to systematize both the assessment process and, even more importantly, the process of putting new regulations on the agenda of national legislation. A new regulation always results in a chain reaction influencing key determinants of health, risk factors and, in the last step, health of a population. As the determinants of health are rather at a population and structural level, policies can carefully plan how, by which means and for what funding they will change the status of health determinants. Risk factors are often in the reach of individuals within a population, so, interventions can be planned both at a population and an individual levels.

Another significant issue to discuss is time; realization of the impact of policies needs time. Description of the probable latency of effects is important information that should be considered in the decision-making process. There is a latency period between the planning and implementation of a policy, as well as a lag phase between policy implementation and development of health effects.

\section{CONCLUSIONS}

Air pollution is an important risk factor for health. In the face of environmental problems and resultant health outcomes, policy-makers may attempt to adopt a range of actions to identify and implement the most effective emission reduction measures. Polish case demonstrates public health benefits of the update of $\mathrm{PM}_{10}$ limit value. If policy can achieve reductions in human exposure, potential health benefits will probably constitute a natural consequence.

The presented assessment is substantially simplified; other environmental determinants could be also included in the model, and other risk factors like smoking, occupational risks, diet, physical activity, etc. should be included in the risk factor analysis, and relative risk calculations. However the aim of this work was to develop and test the chain with focus on this simplified impact.

New legislative efforts as a result of political and economic transformations have caused PM levels to fall 
substantially over the last years, and the new standards seem to be appropriate for the new hierarchy of the emission sources. Implementation of more restrictive air quality standards has brought along improvement of health outcomes, such as attributable number of cardio respiratory deaths years.

Effective public health policy needs translating scientific research into policies and practice. Supporting implementation of national legal instruments to control PM level seems very important from the public health policy point of view as also providing guidelines and evidence. Besides, the issue of exposure and health inequalities in relation to ambient air quality requires a broad, cross-sectoral and multisector engagement. A top-down policy health risk assessment model can be one of the main tools in this process, providing harmonized guidance how to seek an evidence-based information, which could serve policy-makers and also be accessible by the media and the general public.

\section{REFERENCES}

1. World Health Organization. Environmental indicator report. Copenhagen: WHO European Environment Agency; 2012 [cited 2013 Dec 19]. Available from: http://www.eea. europa.eu/publications/environmental-indicator-report-2012.

2. Davidson CI, Phalen RF, Solomon PA. Airborne particulate matter and human health: A review. Aerosol Sci Technol. 2005;39:737-49, http://dx.doi.org/10.1080/02786820 500191348 .

3. Rückerl R, Schneider A, Breitner S, Cyrys J, Peters A. Health effects of particulate air pollution: A review of epidemiological evidence. Inhal Toxicol. 2011;23(10):555-92, http://dx.doi. org/10.3109/08958378.2011.593587.

4. Ostro B, Roth L, Malig B, Marty M. The effects of fine particle components on respiratory hospital admissions in children. Environ Health Perspect. 2009;117(3):475-80, http:// dx.doi.org/10.1289/ehp.11848.

5. Brook RD, Rajagopalan S, Pope CA 3rd, Brook JR, Bhatnagar A, Diez-Roux AV, et al. Particulate matter air pollution and cardiovascular disease: An update to the scientific statement from the American Heart Association. Circulation. 2010;121(21):2331-78, http://dx.doi.org/10.1161/CIR. 0b013e3181dbece1.

6. Crouse DL, Peters PA, van Donkelaar A, Goldberg MS, Villeneuve PJ, Brion O, et al. Risk of nonaccidental and cardiovascular mortality in relation to long-term exposure to low concentrations of fine particulate matter: A Canadian national-level cohort study. Environ Health Perspect. 2012;120(5): 708-14, http://dx.doi.org/10.1289/ehp.1104049.

7. Ito K, Mathes R, Ross Z, Nádas A, Thurston G, Matte T. Fine particulate matter constituents associated with cardiovascular hospitalizations and mortality in New York City. Environ Health Perspect. 2011;119(4):467-73, http://dx.doi. org/10.1289/ehp.1002667.

8. Ostro B, Lipsett M, Reynolds P, Goldberg D, Hertz A, Garcia $\mathrm{C}$, et al. Long-term exposure to constituents of fine particulate air pollution and mortality: Results from the California Teachers Study. Environ Health Perspect. 2010;118(3):3639, http://dx.doi.org/10.1289/ehp.0901181.

9. De Hartog JJ, Lanki T, Timonen KL, Hoek G, Janssen NA, Ibald-Mulli $\mathrm{A}$, et al. Associations between $\mathrm{PM}_{2.5}$ and heart rate variability are modified by particle composition and beta-blocker use in patients with coronary heart disease. Environ Health Perspect. 2009;117(1):105-11, http://dx.doi. org/10.1289/ehp.11062.

10. Van Ryswyk K, Wheele A, Wallace L, Kearney J, You H, Kulka R, et al. Impact of microenvironments and personal activities on personal $\mathrm{PM}_{2.5}$ exposures among asthmatic children. J Expo Sci Environ Epidemiol. 2014;24:260-8, http:// dx.doi.org/10.1038/jes.2013.20.

11. Kowalska M, Skrzypek M, Danson F, Kasznia-Kocot J. Relative risk of total and cardiovascular mortality in the elderly associated to short-term increases of $\mathrm{PM}_{2.5}$ concentrations in ambient air. Pol J Environ Stud. 2012;21(5):1279-85.

12. Kowalska M, Zejda J, Skrzypek M. Short-term effects of ambient air pollution on daily mortality. Pol J Environ Stud. 2010;19(1):101-5. 
13. Kowalska M, Zejda J, Ośródka L, Klejnowski K, Krajny E, Wojtylak M, et al. Air pollution and daily mortality in the Urban Area of Katowice comparison of 2 periods 1994-95 and 2001-2002. Pol J Environ Stud. 2008;17(5):733-8.

14. Kowalska M, Hubicki L, Zejda J, Ośródka L, Krajny E, Wojtylak M. Effect of ambient air pollution on daily mortality in Katowice Conurbation, Poland. Pol J Environ Stud. 2007;16(2):227-32.

15. Jędrychowski W, Perera F, Mrożek-Budzyn D, Mróz E, Flak E, Spengler DJ, et al. Gender differences in fetal growth of newborns exposed prenatally to airborne fine particulate matter. Environ Res. 2009;109:447-56, http://dx.doi. org/10.1016/j.envres.2009.01.009.

16. Jędrychowski W, Perrera FP, Maugeri U, Mróz E, Klimaszewska-Rembiasz M, Flak ES, et al. Effect of prenatal exposure to fine particulate matter on ventilatory lung function of preschool children of non-smoking mothers. Paediatr Perinat Epidemiol. 2010;24:492-501, http://dx.doi.org/10.1111/ j.1365-3016.2010.01136.x.

17. Jedrychowski W, Perera FP, Maugeri U, Spengler J, Mroz E, Flak E, et al. Prohypertensive effect of gestational personal exposure to fine particulate matter. Prospective cohort study in non-smoking and non-obese pregnant women. Cardiovasc Toxicol. 2012;12:216-25, http://dx.doi.org/10.1007/s12012012-9157-z.

18. Jedrychowski W, Perera FP, Spengler JD, Mroz E, Stigter L, Flak E, et al. Intrauterine exposure to fine particulate matter as a risk factor for increased susceptibility to acute bronchipulmonary infections in early childhood. Int J Hyg Environ Health. 2012;216:395-401, http://dx.doi.org/10.1016/ j.ijheh.2012.12.014.

19. Kloog I, Melly SJ, Ridgway WL, Coull BA, Schwartz J. Using new satellite based exposure methods to study the association between pregnancy $\mathrm{PM}_{2.5}$ exposure, premature birth and birth weight in Massachusetts. Environ Health. 2012;11:40.

20. Kowalska M, Skrzypek M. Environmental burden of disease (EBD) and the possibility of using the method for estimating health effects related to $\mathrm{PM}_{2.5}$ exposure. Hyg Public Health. 2014;49:33-8.

21. Boldo E, Medina S, le Tertre A, Hurley F, Mücke HG, Ballester F, et al. Apheis. Health impact assessment of longterm exposure to $\mathrm{PM}_{2.5}$ in 23 European cities. Eur J Epidemiol. 2006;21:449-58, http://dx.doi.org/10.1007/s10654-0069014-0.

22. World Health Organization. Air quality guidelines for Europe. Copenhagen: WHO Regional Office for Europe; 1987.

23. World Health Organization. Air quality guidelines for Europe. 2nd ed. Copenhagen: WHO Regional Office for Europe; 2000.

24. World Health Organization. Air quality guidelines: Global update 2005, particulate matter, ozone, nitrogen dioxide and sulfur dioxide. Copenhagen: WHO Regional Office for Europe; 2006 [cited 2013 Dec 1]. Available from: http://apps. who.int/iris/bitstream/10665/69477/1/WHO_SDE_PHE_ OEH_06.02_eng.pdf.

25. Anderson HR. Air pollution and mortality: A history. Atmos Environ. 2009;43:142-52, http://dx.doi.org/10.1016/ j.atmosenv.2008.09.026.

26. Samoli E, Analitis A, Touloumi G, Schwartz J, Anderson HR, Sunyer J. Estimating the exposure-response relationship between particulate matter and mortality within the APHEA multicity project. Environ Health Perspect. 2005;113:88-95, http://dx.doi.org/10.1289/ehp.7387.

27. University of Southern Denmark [Internet]. Work package 2 - Dissemination of the results. Deliverable 9: Dissemination report of RAPID [cited 2013 Dec 1]. Available from: http://static.sdu.dk/mediafiles//D/6/D/\%7BD6D24A688D0A-4586-9145-2832978DE5AA\%7DWP2\%20Deliverable\%209.pdf.

28. Gulis G, Mekel O, Adam B, Cori L. Assessment of population health risks of policies. New York: Springer Science+Business Media; 2014.

29. Fenger J. Air pollution in the last 50 years - From local to global. Atmos Environ. 2009;43:13-22, http://dx.doi. org/10.1016/j.atmosenv.2008.09.061. 
30. [Regulation of the Council of Ministers of 13 September 1966 on concentration limit of substances in ambient air. J Laws 1966, No. 42, item 253 and 254]. Polish.

31. [The Act of 31 November 1980 on protection of ambient air. J Laws 1980, No. 24, item 89]. Polish.

32. [The Act of 12 February 1990 of air protection against pollution. J Laws 1990, No. 15, item 92]. Polish.

33. [The Act of 28 April 1998 of permissible values of concentrations of pollutants in the air. J Laws 1998, No. 55, item 355]. Polish.

34. [The Act of 22 June 2002 of admissible levels of certain substances in air, alarm levels of certain substances in air and margin of tolerance for the maximum levels of certain substances. J Laws 2002, No. 87, item 796]. Polish.

35. [Regulation of the Minister of the Environment of 5 December 2003 on values of references for certain substances in air. J Laws 2003, No. 1, item 12]. Polish.

36. [Regulation of the Minister of the Environment of $24 \mathrm{Au}-$ gust 2012 on levels of certain substances in air. J Laws 2012, No 0, item 1031]. Polish.

37. Pastuszka JS, Górny RL, Pajdo S, Cimander B, Klinik M. [Studies of the relationship between concentrations of the total suspended particles (TSP) and PM-10 in ambient air in 3 Polish towns]. Ochr Powietrza Probl Odpadow. 1999;5:179-82. Polish.

38. Pastuszka JS, Sosnowska M. [Study of the relationship between $\mathrm{PM}_{10}$ concentrations measured by TEOM (Tapered Element Oscillating Microbalance) and the manual highvolume sampler - To enable assessment of historical exposure]. Ochr Powietrza Probl Odpadow. 2009;42:77-83. Polish.

39. Council Directive 1999/30/EC of 22 April 1999 relating to limit values for sulphur dioxide, nitrogen dioxide and oxides of nitrogen, particulate matter and lead in ambient air. Off J Eur Communities L 163/41, p. 41-60 (Jun 29, 1999).

40. [The Act of 3 March 2008 of levels of certain substances in air. J Laws 2008, No. 47, item 281]. Polish.
41. [The Act of 17 December 2008 of estimate levels of certain substances in air. J Laws 2009, No. 5, item 31]. Polish.

42. [The Act of 26 January 2010 of values of references for certain substances in air. J Laws 2010, No. 16, item 87]. Polish.

43. Directive 2008/50/EC of the European Parliament and of the Council of 21 May 2008 on ambient air quality and cleaner air for Europe. Off J Eur Union L 152/1, p. 1-44 (Jun 11, 2008).

44. European Environment Agency. Air quality in Europe - 2012 report. Copenhagen: The Agency; 2012 [cited 2013 Dec 19]. Available from: http://www.eea.europa.eu/publications/airquality-in-europe-2012.

45. European Environment Agency. Air quality in Europe - 2013 report. Copenhagen: The Agency; 2013 [cited 2013 Dec 19]. Available from: http://www.eea.europa.eu/publications/airquality-in-europe-2013.

46. Council Directive 96/62/EC of 27 September 1996 on ambient air quality assessment and management. Off J Eur Communities L 296/55, p. 55-63 (Nov 21, 1996).

47. Council Decision of 27 January 1997 establishing a reciprocal exchange of measuring ambient air pollution within the Member States (97/101/EC). Off J Eur Communities L 35/14, p. 14-22 (Feb 5, 1997).

48. Directive 2000/69/EC of the European Parliament and of the Council of 16 November 2000 relating to limit values for benzene and carbon monoxide in ambient air. Off J Eur Communities L 313/12, p. 12-21 (Dec 13, 2000).

49. Directive 2002/3/EC of the European Parliament and of the Council of 12 February 2002 relating to ozone in ambient air. Off J Eur Communities L 67/14, p. 14-30 (Mar 9, 2002).

50. Commission Decision of 29 April 2004 laying down a questionnaire to be used for annual reporting on ambient air quality assessment under Council Directives 96/62/EC and 1999/30/ EC and under Directives 2000/69/EC and 2002/3/EC of the European Parliament and of the Council (2004/461/EC). Off J Eur Union L 156/78, p. 78-125 (Apr 30, 2004).

51. Schwartz J. Health effects of air pollution from traffic: Ozone and particulate matter. In: Fletcher T, McMichael AJ, 
editors. Health at the crossroads: Transport policy and urban health. London: London School of Hygiene and Tropical Medicine; 1997. p. 61-82.

52. O'Neill MS, Loomis D, Aburto VHB, Gold D, Hertz-Picciotto I, Castillejos M. Do associations between airborne particles and daily mortality in Mexico City differ by measurement method, region, or modeling strategy? J Expo Sci Environ Epidemiol. 2004;14:429-39, http://dx.doi.org/ 10.1038/sj.jea.7500341.

53. Deck LB, Post ES, Smith E, Wiener M, Cunningham K, Richmond K. Estimates of the health risk reductions associated with attainment of alternative particulate matter standards in 2 U.S. cities. Risk Anal. 2001;21:821-36, http:// dx.doi.org/10.1111/0272-4332.215154.

54. File TM. The epidemiology of respiratory tract infections. Semin Respir Infect. 2000;15(3):184-94, http:/dx.doi.org/ 10.1053/srin.2000.18059.

55. Wojtyniak B, Goryński P, Moskalewicz B. [Heath status of Polish population and its determinants]. Warszawa: Narodowy Instytut Zdrowia Publicznego Państwowy Zakład Higieny; 2012 [cited 2013 Dec 10]. Available from: http://wwwh. pzh.gov.pl. Polish.

56. Pastuszka JS, Rogula-Kozłowska W, Zajusz-Zubek E. [Characterization of $\mathrm{PM}_{10}$ and $\mathrm{PM}_{2.5}$ and associated heavy metals at the crossroads and urban background site in Zabrze, Upper Silesia, Poland, during the smog episodes]. Environ Monit Assess. 2010;168:613-27, http://dx.doi.org/10.1007/ s10661-009-1138-8. Polish.
57. Junninen H, Mønster J, Rey M, Cancelinha J, Douglas K, Duane M, et al. Quantifying the impact of residential heating on urban air quality in a typical European coal combustion region. Environ Sci Technol. 2009;43:7964-70, http:// dx.doi.org/10.1021/es8032082.

58. Powell S. Particulate matter in the air and its origins in coalburning regions. Environ Sci Technol. 2009;43(22):8474, http://dx.doi.org/10.1021/es9030479.

59. Zatoński W. Closing the health gap in European Union. Warszawa: Cancer Epidemiology and Prevention Division of Maria Skłodowska-Curie Memorial Cancer Center and Institute of Oncology; 2008.

60. Brożek GM, Zejda JE, Kowalska M, Gębuś M, Kępa K, Igielski M. Opposite trends of allergic disorders and respiratory symptoms in children over a period of large-scale ambient air pollution decline. Pol J Environ Stud. 2010; 19:1133-8.

61. Bandosz P, O’Flaherty M, Drygas W, Rutkowski M, Koziarek J, Wyrzykowski B, et al. Decline in mortality from coronary heart disease in Poland after socioeconomic transformation: Modeling study. BMJ. 2012;344(8136):1-10.

62. Drygas W. [Streamlining the early diagnostic testing and the active care of persons with the risk of the development of the ischaemic heart disease]. In: Goryński P, Wojtyniak K, Kuszewski K, editors. [Monitoring of expected effects of the realization of the National Program of the Health 19962005]. Warszawa: Ministerstwo Zdrowia i Państwowy Zakład Higieny; 2005. Polish.

This work is available in Open Access model and licensed under a Creative Commons Attribution-NonCommercial 3.0 Poland License - http://creativecommons.org/ licenses/by-nc/3.0/pl/deed.en. 